\title{
How to write an oral dialect or about some problems of the Tsakonian Corpus
}

Maxim Kisilier

Hellenic Institute, Saint-Petersburg State University; Department of Comparative and

Areal Linguistics, Institute for Linguistic Studies (RAS), Russia

https://doi.org/10.36505/ExLing-2016/07/0017/000276

\begin{abstract}
Hellenic Institute of the Saint-Petersburg State University in collaboration with the Institute for Linguistic Studies of the Russian Academy of Sciences organized more than twenty expeditions to South Kynouria in Peloponnese (Greece) in order to describe the Tsakonian dialect. During these expeditions its participants collected a large number of oral texts in Tsakonian and it was decided to create a Tsakonian corpus so that this very interesting linguistic material could be easily accessed. This paper provides the first description of the project and discusses its current problems.
\end{abstract}

Key words: Modern Greek dialectology, Tsakonian, language corpus.

\section{Introductory remarks}

Modern Greek dialectology has a rather long history. Many institutions in- or outside Greece possess large collections of Modern Greek dialect materials from various Greek speaking regions. Unfortunately the major part of them remains unknown and unused not only by typologists, but even by specialists in Modern Greek dialectology. Short dialect texts from these collections are sometimes published as supplements to linguistic papers (cf.: Kisilier 2009: 406-411; 2014: 342-344), but they can hardly be used for serious linguistic analysis as they provide just a general idea of the dialect and may lack some very important features. More often certain samples from these collections appear in linguistic articles to illustrate a statement of the author.

However when the statement is false, the reader may be led to incorrect interpretations of the example or even to erroneous conclusions in general since he has no opportunity to check this example or statement. Thus Russian linguist Mikhail Sergievskiy who was the first to describe the verb system of Azov Greek found perfect forms in this dialect (Sergievskiy 1934: 582-583). So Azov Greek could be grouped together with other few Modern Greek dialects that have perfect/pluperfect along with aorist. All other descriptions of Azov Greek never mention perfect forms, while the analysis of the modern state of the verb in the dialect based on recently collected data doesn't let

ExLing 2016: Proceedings of $7^{\text {th }}$ Tutorial and Research Workshop on Experimental Linguistics, 27 June - 2 July 2016, Saint Petersburg, Russia 
to discover any trace of perfect forms or any appropriate place for them within the verb system (Kisilier 2009: 193-205). This ambiguous situation can be easily explained. Sergiyevsky found perfect forms in the poems by Georgy Kostoprav who tried to create a special language for Azov Greek literature based both on local idioms and on some Demotic features that in fact did/do not exist in the dialect like perfect forms (Kisilier 2009: 13-14).

The progress of modern technologies gives hope that one day there will be no need to look for dialect examples in books and articles, but in text corpora. Nowadays there is still no open access corpus of any Modern Greek dialect that can be really helpful for linguistic research (cf.: http://griko.project.uoi.gr/), but many attempts in this direction are already made. In this paper I am going describe briefly the project of Tsakonian corpus and some problems I had to face.

\section{About Tsakonian dialect and Tsakonian project}

Tsakonian is one of Modern Greek dialects of Peloponnese. It is generally believed that Tsakonian can be traced back directly to the Ancient Doric Laconian. Different sources provide different number of speakers - from 200 in (Salminen 2007) up to 8000 in (Kontosopoulos 2001: 3). Since 2008 Hellenic Institute of the Saint-Petersburg State University in collaboration with the Institute for Linguistic Studies of the Russian Academy of Sciences organized more than 20 expeditions to the Tsakonian speaking area (http://iling.spb.ru/index.html?language=en) and now disposes approximately 250 hours of audio and 30 hours of video recordings and 147 linguistic and ethnographic questionnaires (Kisilier 2014). The most interesting texts were transcribed and supplied with detailed interlinear morpheme-by-morpheme glossing that takes into account all inflectional peculiarities.

One of the goals of these expeditions was to collect lexical data using the questionnaire of "Minor dialectological Atlas of Balkan languages (Domosiletskaya et al. 1997). At the present stage the words are put into Field Linguist's Toolbox together with subdialectal variants and grammatical forms, for example:

1. mountain: Jina masc. [Vaskina, Kastanitsa], sina masc. [Melana]; pl. Sinu; genitive th Sinu - korfá tu finu 'top of the mountain'.

2. to bite: katsinu [Vaskina, Melana, Tyros], gatsinu [Prastos], tatsinu [Kastanitsa]; fem. katşina; neutr. katsinda; aorist $1 \mathrm{Sg}$ ekatşika/ ekatsia, 3Sg. ekatsitselekatsite; perfect participle katsit' $e$; subjunctive imperfective 1Sg. na=katsinu, 3Sg. na=katsini, 3Pl. na=katsinoi; subjunctive perfective 1Sg. na=katsiu, 3Sg. na=katsi, 3Pl. na=katsinoi. 
Local community, especially the Tsakonian Archives (http://www.tsakonianarchives.gr/) always tried to help us and demonstrated a deep interest in our activities and results. It became evident that they should have access to our materials and they ought to be able to use them in their attempt to provoke interest towards Tsakonian in the younger generation. Some years before we started our activities in Tsakonia Demotic School of Leonidio (municipal center of the region) created online dictionary of Tsakonian (http://dimleonid.ark.sch.gr/?page_id=28). They used the "Dictionary" by Michael Deffner (1923) and asked pupils to go their grandparents in order to have some words translated from Modern Greek into Tsakonian. This online dictionary is, certainly, very small (only 4635 entries) and inconsistent because the quality of the data collected by pupils is very uneven. However this attempt demonstrated that Tsakonian youngsters are ready to deal with Tsakonian, especially if they see its application and if they realize that Tsakonian is not so old-fashioned as they used to believe and it can be accessed by means of the modern technologies.

\section{About Tsakonian corpus}

When it was decided to create a Tsakonian corpus, it became evident that corpus must be available for both linguists and local community. This decision has its advantages and disadvantages. Collaboration with the Tsakonian Archives, on the one hand, makes it possible to incorporate some already published dialect texts together with the recently collected ones. So the corpus will become more diachronically representative and rich in its vocabulary. On the other hand, it presupposes that non-linguists should be able to read Tsakonian dialect and we cannot content just with IPA.

Famous specialist in Tsakonian Thanasis Costakis has invented Tsakonian alphabet based on Greek graphics. The varieties of this alphabet are widely used in local editions of dialect texts. Despite certain inconsistencies, Costakis alphabet can be easily transformed into IPA, but it is totally inapplicable for corpus because it makes use of particular diacritics that is absent from standard fonts. This problem can be somehow solved for printed editions or by means of uploaded fonts or virtual keyboards. However I am sure that most local users are going to visit the site from their mobile devices and that is why a different alphabet is required.

On October, 30 2015 I introduced a new alphabet to local community. I thought that it was to be very easy and it had to avoid any possible ambiguity. The user should not depend on his knowledge of 
Ancient Greek and choose among $\iota, \eta, \varepsilon \iota, o \iota$ and $u$ as he looks for a word with /i/ in it. Actually I followed the example of Russian linguists who created Greek-based alphabet for Georgian Pontic and Azov Greek (cf.: Kisilier 2009: 11-12). Thus the new Tsakonian was supposed to get rid of traditional digraphs in vowel system (/i/ is expressed only by means of $\iota, \omega$ is not used at all, $v$ is $/ u / /)$. Tsakonian has a number of peculiar consonants (cf.: Haralampopoulos 1980: 26-83), and I decided to adopt some clusters for them: $\gamma x / g /($ vs $\gamma / \gamma /), \zeta \zeta / 3 /, \pi \chi / \mathrm{p}^{\mathrm{h}} /, \sigma \sigma / \mathrm{J} /$ (as the dialect has no geminates), $\tau \zeta / \mathrm{d} \widetilde{z} /, \tau \sigma / \mathrm{t} \widetilde{\mathrm{s}} /, \tau \sigma \sigma / \mathrm{T} /$, and $\tau \chi / \mathrm{t}^{\mathrm{h}} /$. Sometimes it is important to indicate palatal consonants (Kisilier, Fedchenko 2011) and I proposed to introduce $\eta$ as palatal index: $\lambda \eta / \mathrm{l}^{\mathrm{i}} /$,

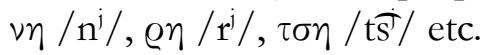

However local intellectuals did not approve of the new alphabet because it is totally different from the one by Costakis which they regard as an important ground of the modern Tsakonian culture. And this stalemate is still not resolved.

\section{Acknowledgements}

This research was supported by the Russian Science Foundation (project No 15-1800062) and the Russian Foundation for Humanities (project No 14-04-00581).

\section{References}

Salminen, T. 2007. Europe and North Asia In Moseley, C. (ed.) 2007. Encyclopedia of the world's endangered languages, 211-280. London; New York, Routledge.

Deffner, M. 1923. Lexicon tis Tsakonikis dialektou. Athens, Typography "Estia"; Meissner \& N. Karagadouris.

Kontosopoulos, N. G. 2001. Dialektoi kai idiomata tis neas ellinikis. Athens, Grigori Publishers.

Haralampopoulos, A. L. 1980. Fonologiki analysi tis Tsakonikis dialektou. Doctoral dissertation. Arostotle University of Thessaloniki, Thessaloniki.

Domosiletskaya, M.V., Zhugra, A.V., Klepikova, G.P. 1997. Malyy dialektologicheskiy atlas balkanskikh yazykov. Lexical questionnaire. St. Petersburg University.

Kisilier, M.L. 2014. Tsakonskiy dialekt: novyy vzglyad In Vydrin, V.F., Kuznetsova, N.V. (eds.) 2014. Ot Bikina do Bambalyumy, iz varyag v greki. Ekspeditsionnye etyudy v chest' Eleny Vsevolodovny Perekhval'skoy, 330-348. St. Petersburg, Nestor-Istoria.

Kisilier, M.L. (ed.) 2009. Lingvisticheskaya i etnokul'turnaya situatsiya v grecheskikh selakh Priazov'ya. Po materialam ekspeditsiy 2001-2004 g. St. Petersburg, Aleteya.

Kisilier, M.. L., Fedchenko, V. V. 2011. K voprosu o myagkikh soglasnykh v tsakonskom dialekte novogrecheskogo yazyka. Indo-European Linguistics and Classical Philology Yearbook XV, 259-266.

Sergievskiy, M. V. 1934. Mariupol'skie grecheskie govory. Opyt kratkoy kharakteristiki. Izvestiya AN SSSR. Otdelenie obshchestvennykh nauk 7, 533-587. 